\title{
MENTAL DERANGEMENT AS A MANDATORY ELEMENT OF LIMITED SANITY
}

DOI: 10.36740/WLek202012241

\author{
Anna S. Politova', Mykhailo 0. Akimov' ${ }^{2}$, Liubov M. Knyazkova' \\ 'DONETSK LAW INSTITUTE OF MINISTRY OF INTERNAL AFFAIRS OF UKRAINE, MARIUPOL, UKRAINE \\ 2NATIONAL ACADEMY OF INTERNAL AFFAIRS, KYIV, UKRAINE
}

\begin{abstract}
The aim: Complex analysis of theoretical and practical aspects of study of mental derangement as a mandatory element of limited sanity and development of new approaches to such state's assessment.

Materials and methods: An analysis of criminal legislation and researches made by scientists from Brazil, Denmark, Great Britain, Portugal and the USA concerning mental derangements of persons who committed crimes and were considered as having limited sanity, publications in mass media, analytical materials, judicial practice (with the purpose to define certain types of crimes and types of mental derangements of such group of people) has been made. For comparison analysis within the framework of study of problems of mental derangement as a mandatory element of limited sanity 1422 court verdicts were selected from Unified Register of Court Rulings of Ukraine (as of August 2020) concerning persons who committed criminal offences under circumstances which allow to consider such persons as having limited sanity. The methods of statistical analysis, system structural method, method of legal phenomenon system analysis and comparative method were applied during the research.

Conclusions: Due to significant increase of quantity of people with mental derangements it is necessary to envisage legally types of mental derangements qualified as limited sanity. This will allow to oblige bodies of criminal justice to conduct mandatory psychiatric examinations after all kinds of crimes when there are grounds to assume that the person during criminal offence commitment was not able to fully understand his (her) actions and (or) control. Consequently, every person having mental derangement and considered as having limited sanity should be subject of compulsory measures of medical care during sentencing, and duration of such care should be legally stipulated with regard to the type of mental derangement.

To prevent commitment another crimes by persons with mental derangement and considered as having limited sanity it is necessary to develop correlation programs with certain schemes of treatment, separate categories of people in need of psychiatric help, relevant financing and coordination mechanisms for interaction between the law enforcement bodies and local governance.
\end{abstract}

KEY WORDS: criminal offence, limited sanity, mental derangement, compulsory measures of medical care

Wiad Lek. 2020;73(12 p. II):2951-2956

\section{INTRODUCTION}

Study of the person committed criminal offence always was a metter of interest not only to researchers in the field of criminal law and criminology, but to psychologists and psychiatrists. This is due to the theories of criminal behavior explanation because the issue of causes of crime commitment is still not properly clarified.

Sanity is mandatory feature to be established for bringing person to criminal responsibility. This characteristic of person who committed criminal offence allows defining such person's mental condition, ability to perceive certain deed's unlawfulness and to control own actions during its commitment.

It is undeniable fact that person's criminal behavior is influenced by different factors (social-economic, political, historical, cultural etc.) that taken together cause stress situations, deterioration of emotional state and emergence of mental derangements. For example, economical instability in the world due to SARS COVID-2019 pandemic, tense political situation and other factors predetermined the increase of crimes committed quantity both in the world and in Europe. According to Numbeo data, as of July 2020 Venezuela is the country with the highest crime rate $(84,36)$ in the world, and Ukraine - in Europe $(48,84)$ [1].

Criminal responsibility and the insanity defense are topical issues confronting the criminal justice system. To ensure due process, uphold judicial integrity and maintain the integrity of criminal proceedings, courts must determine when a defendant is responsible for alleged criminal acts, and when the insanity defense is applicable. For every criminal offence, two requirements must be established: the actus reus and the mens rea [2, p. 685]. While the actus reus denotes an overt or proscribed act, mens rea on the contrary is concerned with the criminal intent to perform the actus reus [3].

That's why defining of mental condition of the person committed criminal offence has crucial importance for criminal proceedings (namely in case of establishing mental derangement - for application of necessary compulsory measures of medical care). Mental derangement 
and criminal offence committed is a double-egged sword which ignited a lot of discussion between psychiatrists and lawyers. If sensible middle is found, it is possible to develop special rules of behavior with people who committed criminal offences having mental derangements.

\section{THE AIM}

The aim of this article is to present a complex analysis of theoretical and practical aspects of mental derangement study as a mandatory element of limited sanity and formulation of new approaches to such state's assessment.

\section{MATERIALS AND METHODS}

An analysis of criminal legislation and researches made by scientists from Brazil, Denmark, Great Britain, Portugal and the USA concerning mental derangements of persons who committed crimes and were considered as having limited sanity, publications in mass media, analytical materials, judicial practice (with the purpose to define certain types of crimes and types of mental derangements of such group of people) has been made.

For comparison analysis within the framework of study of problems of mental derangement as a mandatory element of limited sanity 1422 court verdicts were selected from Unified Register of Court Rulings of Ukraine as at August 2020 concerning persons who committed criminal offences under circumstances which allow to consider such persons as having limited sanity.

The method of statistical analysis, system structural method, method of legal phenomenon system analysis and comparative method were applied during the research.

\section{REVIEW AND DISCUSSION}

The concept of responsibility is in focus when we consider the human rights of people with mental health problems. It is a general principle of law "that the person liable to be punished should at the time of his crime have had the capacity to understand what he is required by law to do, and to control his conduct in the light of such decisions. Normal adults are generally assumed to have these capacities, but they may be lacking where there is mental disorder or immaturity, and the possession of these normal capacities is very often signified by the expression 'responsible for his action' " [4]. If someone is not responsible for his/her actions then it is argued they should not be punished for them and instead diverted to the appropriate services [5].

It should be stressed that in some foreign countries people with mental illness are over-represented in the criminal justice system. The 2011-2012 Annual Report of the Correctional Investigator found that $36 \%$ of federal offenders were identified at admission as requiring psychiatric or psychological follow-up, and $45 \%$ of male inmates and 69 $\%$ of female inmates received institutional mental health care services [6]. The over-representation of people with mental illness in the corrections system may be increasing over time. Between 1997 and 2010, symptoms of serious mental illness reported by federal offenders at admission increased by $61 \%$ for males and $71 \%$ for females [7]. Notably the partial excuse of diminished responsibility due to intoxication - in 2013 in Germany, out of 935,788 accused, $749(0,08 \%)$ were found totally irresponsible and 17,968 $(1,9 \%)$ partially irresponsible [8].

However, only some states are keeping records of mentally ill persons who committed criminal offences and are treated during their sentence. For example, there is no record of persons having limited sanity in Ukraine. Instead Department of Criminal Punishments of Ministry of Justice of Ukraine is registering data on restraint measures commutation, custodial sentences, non-custodial sentences, judgments of acquittal, quantity of convicted men, women, juveniles, persons sentenced for life imprisonment. Meanwhile, according to statistics 1,2 mln of Ukrainians (e.g. more than $3 \%$ of the population) suffer from mental derangements, and this number is growing every year. Ukraine is ranked first in Europe on quantity of mental derangements among population - almost $2 \mathrm{mln}$ of our fellow countryman become patients of mental health clinics every year $[9$, p. 105].

Study of mental derangement as a mandatory element of limited sanity, requires two aspects to be considered. The first one (psychiatric) means that person to whom state condemnation (in the form of criminal responsibility) is applied may have mental derangement that does not deprive him (or her) of the ability to understand meaning of his (or her) actions and control them. Whereas such derangements belong to mentality, consciousness and are of critical importance for defining the matter of sanity, they should be taken into account by court in a certain way. The second (legal) consists of constant tendency to measure of punishment individualization and - due to this - increased attention to the subjects of crime. That's why combination of these circumstances define the main goal to be achieved by introducing the institute of limited sanity - establishing legal grounds and mechanisms that enable understanding by court (via forensic psychiatric examination of the defendant) the meaning of the latter's mental disorder (which does not excluded his (or her) sanity) for resolve the issue of his (or her) guilt and responsibility.

When defining limited sanity, it is of utmost importance to answer properly the question of the ability of a subject to realize the actual nature and public danger of the actions (inaction) or to direct them, psychiatrists based on medical and legal (psychological) criterion of sanity / insanity rely on data obtained from a pathopsychological examination $[10$, p. 44].

World Health Organization specialists point out that mental health should be seen as a valued source of human capital or well-being in society. It contributes to individual and population health, happiness and welfare, enables social interaction, cohesion and security, and feeds national output and labor force productivity. We need good mental health to succeed in all areas of life [11]. In this way person's mental health is a complex phenomenon 
mainly consist of his (or her) social and communication skills; consequently, mental health status does not defined exclusively by presence or absence of mental derangement. Regarding this, mental disorders represent disturbances to a person's mental health that are often characterized by some combination of troubled thoughts, emotions, behavior and relationships with others. Examples of mental disorders include depression, anxiety disorder, conduct disorder, bipolar disorder and psychosis [12]. In addition to this, there are three basic approaches to deal with mental disorders as grounds for excluding criminal responsibility:

(1) The overwhelming majority of legal orders accept mental disorder as separate ground - mostly labeled "excuse" or "defense" - for excluding criminal responsibility. Although the criteria look very similar, the resulting practical differences range from very restrictive application, notably in the English-speaking world, to fairly frequent use in some civil law countries.

(2) A small group of legal orders - a couple of American states - admits mental disorders only insofar as they constitute mistake or involuntariness, i.e. negate the requirement of intent or, rather in theory than in practice, of a voluntary act.

(3) Another small group - mainly Sweden which, however, is gradually returning to the mainstream - adopted a unified system of social control in which mental disorders are only relevant to determine the suitable kind of treatment of the offender [13, p. $51 ; 14$, p. $168-181 ; 15 ; 16$, p. 26].

It all proves that main argument in favor of limited sanity concept means the absence of clear boundaries between different in severity mental derangements. On the contrary, there are gradual transitions that cause confusion - to consider such person sane, or having limited sanity, or insane. This is also stressed by M. Rahmdel, who notes that the problem is that certain people suffer from less severe mental illnesses that, while still debilitating, are neither medically nor psychologically categorized as insanity. That is, although these illnesses influence both their faculty of decision-making and their behavior, the law recognizes these people as being fully criminally liable. Thus, apparently the former law held more conformity with scientific rules. In practice, courts regard such cases as instances of mitigating circumstance $[17$, p. 202].

It should be stressed that the International Statistical Classification of Diseases and Related Health Problems (ICD-10), approved by the World Health Organization in 2007, stipulates mental and behavioral disorders in chapters F00-F99. These include, among others, F00-F09. Organic, including symptomatic, mental disorders (F00. Dementia in Alzheimer's disease, F01. Vascular dementia, F02. Dementia in other diseases classified elsewhere, F06. Other mental disorders due to brain damage and dysfunction and to physical disease), F10-F19. Mental and behavioral disorders due to psychoactive substance use (F10. Mental and behavioral disorders due to use of alcohol, F11. Mental and behavioral disorders due to use of opioids, F12. Mental and behavioral disorders due to use of cannabinoids, F13. Mental and behavioral disorders due to use of sedatives or hypnotics), F20-F29. Schizophrenia, schizotypal and delusional disorders etc. [18].

Most researchers, defining medical criterion of limited sanity, examine all mental derangements that does not exclude sanity (in other words - does not reach the psychotic level) at the moment of certain person's crime commitment. This is about endogenous, exogenous mental diseases, vascular disorders, infectious lesions, psychoactive substances dependence, statuses conditioned by developmental pathology. But despite of nosological belonging of mental derangement the main thing is to determine, firstly, whether the person had mental derangement at the moment of crime commitment, and secondly, what was such derangement's level of influence upon the decision to commit crime.

Research on the topic: "Crime, psychiatric diagnosis and victims' profiles: a study with the sample of a criminal-psychiatric ward in São Paulo" was carried out by E. H. Teixeira and P. Dalgalarrondo in 2005. The records of 269 patients were analyzed, considering only male patients whose medical reports had already been included in the criminal-psychiatric records. Psychotic disorders were the most common findings (58 \%). The most common type of crime was murder or murder attempt $(52,8 \%)$, with a significant correlation between psychotic disorders and this type of crime $(\mathrm{p}<0.05)$. These crimes led to death in 89,7 $\%$ of the cases, and in $34,5 \%$ the victim was a close relative. Mentally retarded patients committed proportionally more sexual crimes when compared to psychotic patients and considering only sexual crimes or murder attempts $(\mathrm{p}<0.05)$. In $78,5 \%$ of all sexual crimes the victims were under 14 years old [19, p. 192-194].

Meanwhile according to the data received by J. Garbayo and M. J. Relvas Argôlo, the most prevalent diagnosis were psychotic disorders (67\%) followed by mental retardation $(15,2 \%)$, disorders due to the use of psychoactive substances $(7,3 \%)$, personality disorders $(4,5 \%)$, among others. Most of them (71\%) had been under previous psychiatric treatment [20, p. 247-252]. A group of scientists headed by S. Fazel, comparing the risk of increase of criminal behaviour among patients with established diagnosis "epilepsy" and among general population, has recorded such index increase 1,5 times among former [21].

We selected 1422 court verdicts from Unified Register of Court Rulings of Ukraine concerning persons who committed criminal offences under circumstances which allow to consider such persons as having limited sanity. It was observed that from 1406 persons who were actually consider as such 185 were registered as psychiatrists' patients with a diagnoses of mental deficiency, 222 - schizophrenia, 296 - imbecility, 74 - dementia combined with emotional-volitional instability, 148 - oligophrenia with psychopathic-like behavior, 148 - organic personality disorder, 185 - abnormal personality, 111 - epilepsy, 37 exhibitionism and post-traumatic stress disorder. Thus it is possible to conclude that person considered as having limited sanity can have any mental or behavioral derangement, but the most common are F06. Other mental disorders due 
to brain damage and dysfunction and to physical disease, F20. Schizophrenia, F65. Disorders of sexual preference, F70-F79. Mental retardation, F80. Specific developmental disorders of speech and language.

V. Batyrgareieva also underlines that mental disorders are common among the recidivists. By the results of her research 52,9\% recidivists who were subjected to forensic psychiatric examination were found to have certain psychical anomalies which do not exclude sanity. The most common of them were mental and behavioral derangements caused by use of psychoactive substances (namely alcohol and drugs). Proportion of recidivists with mental anomalies classifies to the chapter F1 of ICD-10 is 59,6\% among all examined by specialists [22]. Moreover, 22,2\% of all examined and found to have mental anomalies classifies to the chapter F6 of ICD-10 are also recidivists [22].

In the meantime either foreign scientists' researches or court rulings analyzed by us have no mention of ICD-10. That's why we consider as argumentative the conclusion that separation of legal from medical descriptors has the obvious advantage of freeing the law from the vagaries of the development of the medical sciences - avoiding the problems created by outdated terminology which plague Paragraph 20 of the German Criminal Code ('pathological mental disorder, profound consciousness disorder, debility or any other serious mental abnormality'). On the other side, the separation has the obvious disadvantage of potentially missing essential features of the relevant phenomena and of creating permanent problems of translation in the legal evaluation of expert opinions [13, p. 53]. On the contrary, explanations of certain types of mental derangements given in criminal legislation would allow avoiding complications in application of punishment to such persons.

Equally debatable is an issue of types of criminal offences committed by persons with mental derangements (most of such studies were conducted by scientists in Russia and in the USA). Instead we are interested in results received in other countries. According to data obtained by group of researches headed by M. P. Pondé, persons with mental derangements committed the following crimes in Brazil (according to its Penal Code): robbery (Article 157), kidnapping and extortion (Article 159), rape (Article 213), indecent assault (Article 214), theft (Article 155), rioting (Article 354), contempt (Article 331), illegal threats (Article 146), fraud (Article 171), conspiracy(Article 288), misappropriation (Article 168), extortion (Article 158), embezzlement (Article 312), use of fraudulent or counterfeit documents (Article 304), receiving stolen goods (Article 180), false identity (Article 309), crimes related to counterfeiting money (Article 290), intimidation (Article 147), escape of a legally imprisoned individual or of an individual submitted to a security measure (Article 351), corruption of minors (Article 218), resistance (Article 329), escaping prison through the use of violence against an individual (Article 352), bodily harm (Article 129), fraudulent misrepresentation (Article 299), kidnapping (Article 148), homicide (Article 121), crime of armed robbery and murder (first-degree murder in accordance with Article 157,
Paragraph 3 of the penal code), drug trafficking crimes (as defined in Article 33 of Brazilian law 11.343/2006), torture (as defined in Article 1 of Brazilian Law 9.455/1997), illegal possession of weapons (as defined in Article 12 of Brazilian Law 10,826/2003) [23, c.10-13]. Other academics studying persons who committed crimes and were considered as having limited sanity note that such persons prone to violent crimes against life and health (murder, bodily injury etc.), sexual crimes or terrorists crimes.

At the same time joint research of D. J. Vinkers, E. de Beurs, M. Barendregt, T. Rinne and H. W. Hoek shows that total prevalence of mental disorders is highest when the main charge is a crime against property $(58,0 \%)$ and lowest when such charge is murder $(40,0 \% ; \mathrm{X} 2=5325,6$, $\mathrm{p}<0,001)$. More specifically, the prevalence of psychotic disorders was relatively high in relation to battery $(17,6$ $\%)$ and / or manslaughter charges (16,0 \%) and relatively low in respect of sexual crimes $(3,2 \%)$ and rape $(5,6 \%$; $\mathrm{X} 2=5325,6, \mathrm{p}<0,001)$. Developmental disorders were especially prevalent in defendants of sexual crimes $(6,9$ $\% ; \mathrm{X} 2=5325,6, \mathrm{p}<0,001)$. Personality disorders were most common in defendants of battery $(53,5 \%)$ and property $(51,7 \%)$ and least common in defendants of sexual crimes $(46,1 \%)$ and assault $(48,2 \%$; X2 $=122,01$, $\mathrm{p}<0,001)$. Cluster B personality disorders were more common in defendants charged with violent crimes (20,9-23,0 \%), whereas cluster C personality disorders were more common in respect of sexual crimes $(7,3 \%$; $\mathrm{X} 2=122,01, \mathrm{p}<0,001)$. An IQ score of 85 and below, or intellectual functioning estimated as being below average, was more common in rape defendants $(14,7 \%$ vs $24,4 \%$; $\mathrm{X} 2=200,62, \mathrm{p}<0,001)$, Alcohol abuse was more common in defendants charged with arson $(27,3 \%)$ and less common in defendants where the charges were sexual $(8,9$ $\%)$ or property related $(7,8 \% ; \mathrm{X} 2=2120,4, \mathrm{p}<0,001)$. Abuse of both cannabis (13,0\%) and hard drugs (24,3\%) was especially high in relation to property crimes (X2 = $2120,4, \mathrm{p}<0.001)$ [24, p. 308].

Finally, according to the results obtained by J. Garbayo та M. J. Relvas Argôlo murder was the most common crime ( $44 \%$ ) followed by crimes against property (26\%), sexual crimes $(11 \%)$, crimes related to drugs (11\%) and others. Intrafamiliar murder was prevailing among mentally retarded population and psychotics. The former generally committed more sexual crimes than the latter [20, p. 247-252].

Similar results were obtained in some ways concerning situation in Ukraine. As our research shows, the most the most common of them are criminal offences against property (584 judgments of conviction, or $41 \%$, and $30 \%$ of them are on charges of theft stipulated by Art. 185 of CC of Ukraine). Running second are criminal offences in the field of circulation of narcotic drugs, psychotropic substances, their analogues or precursors and other criminal offences against public health (298 judgments of conviction, or 20,7 $\%$, and $15,5 \%$ of them are on charges of illicit manufacture, making, acquisition, storage, transportation or shipment of narcotic drugs, psychotropic substances or their analogues 
without the purpose of sale stipulated by Art. 309 of CC of Ukraine). In third place are criminal offences against public safety (221 judgments of conviction, or 15,5\%, and 6,3\% of them are on charges of knowingly false information about the threat to public safety, destruction or damage to property stipulated by Art. 259 of CC of Ukraine).

As for other criminal offences, no defendant was considered according to psychiatric examination reports as having limited sanity in cases of intentional murder (Art. 115 of CC of Ukraine); at the same time every third person charged with intentional grave bodily injury (Art. 121 of CC of Ukraine) was considered by psychiatric examination reports as having limited sanity.

Consequently, we consider at least debatable conclusions made by D.J. Vinkers, E. de Beurs, M. Barendregt, T. Rinne, $\mathrm{H}$. W. Hoek concerning the fact that mental disorders are related to all types of crimes but especially to arson, battery and homicidal attempts or threats [24, p. 307], since any person having mental derangements and being at extreme situation could commit any unlawful actions.

It should be stressed that analysis of crimes committed by persons having mental derangements and considered as having limited sanity proves that one-third of them had been regularly and sufficiently treated as outpatients. Almost half of the offenders were diagnosed with alcohol abuse/dependence and two-thirds with any substance abuse/dependence. Furthermore, almost half were intoxicated during the index crime. Antisocial personality disorder was diagnosed in $25 \%$ of the offenders. Almost half of the offenders were placed in involuntary special care for the ID, which lasted approximately 2 years. Among the last mentioned, two thirds of the nursing care plans lacked recommended structure [25]. In addition other results (which are in line with our outcomes) confirm that mental disorders are most common for men (almost $90 \%$ from all persons considered as having limited sanity); the research made by O. Kozeratska shows that the correlation between men and women is $96,7 \%$ to $3,3 \%$ respectively [26].

Publications on this issues and results obtained during our own research demonstrate that mental derangement could be taken into account by the court during sentencing (naturally as a mitigating circumstance as there is no such in the list of aggravating circumstances) and could by the ground for application of compulsory measures of medical care. However, the mechanism of such taking into account is still does not defined. In certain countries (for example, in Brazil and Denmark) compulsory measures of medical care are very seldom applied to persons who committed crimes and have limited sanity; instead they are referred to psychiatric clinics for treatment. Application of compulsory measures of medical care usually takes place when severe psychiatric illness is diagnosed or a violent crime was committed. In general they are applied only to $20 \%$ of persons who have mental derangements and committed repeated crimes.

As to Ukraine, in almost 1000 judgments of conviction outpatient psychiatric care was compulsory applied at the place of residence, in 222 cases the same took place in correctional facilities; almost 200 judgments of conviction do not contain any mention of application of compulsory measures of medical care.

Consequently we can assume that lawmaker's specification of mental derangement as a mandatory element of limited sanity in criminal legislation was based on the principle of humanity and according to modern foreign tendencies of criminal law development inherent to many countries around the world. But criminal justice system not always has relevant mechanisms of influence on such people, and non-application of compulsory measures of medical care or correlational programs to them leads to commitment of repeated criminal offences.

\section{CONCLUSIONS}

This research allows concluding the existence of necessity to stipulate the list of mental derangements as a mandatory feature of limited sanity in criminal legislation. Unfortunately, bodies of criminal justice not always consider expedient to commission and conduct forensic psychiatric examination to establish presence (or absence) of mental derangements arguing that such examination is compulsory only in cases of certain criminal offences commitment. As a result person who was not a subject of such examination is still considered sane, could commit another criminal offence, and his (or her) mental derangement will become more severe.

Psychological progress in different illnesses diagnostics urges lawmakers in different countries to examine the possibility to release persons having mental derangements from criminal responsibility or consider existence of such derangements as a mitigating circumstance. Significance of such achievements proves criminal legislation dependence on psychology.

We can confidently affirm that persons with mental derangements who are considered as having limited sanity are inclined to recidivism of criminal offences. This postulates mandatory application of compulsory measures of medical care to such persons and normative regulation of duration of such application.

Whereas the quantity of people with mental derangements is increasing during last years, the necessity arises to develop on state level specific correlational programs for persons who are considered as having limited sanity to prevent commitment repeated criminal offences by them. These programs will help to substantiate approaches to treatment schemes, to define people to which urgent mental health care is necessary, to coordinate interaction between law enforcement bodies and local governance. Without such programs introduction the quantity of people with mental derangements who are considered as having limited sanity will only increase, as it is already observed in certain countries.

\section{REFERENCES}

1. Crime Index by Country 2020 Mid-Year. Available from: https:// www.numbeo.com/crime/rankings_by_country.jsp?title $=2020$ mid\&displayColumn $=0$. [reviewed 2020.08.28]. 
2. Adjorlolo S., Agboli J. M., Chan, H. CO. Criminal Responsibility and the Insanity Defense in Ghana: The Examination of Legal Standards and Assessment Issues. Psychiatry, Psychology and Law. 2016;23(5):684695. doi.org/10.1080/13218719.2015.1113606.

3. Zapf, P. A., Golding, S. L., Roesch, R., \& Pirelli, G. (2014). Assessing criminal responsibility. In I. B. Weiner \& R. K. Otto (Eds.), The handbook of forensic psychology (p. 315-351). John Wiley \& Sons, Inc.

4. Laing J.M. Care or Custody? Mentally Disordered Offenders in the Criminal Justice System. Oxford: Oxford University Press, 1999. 375 p.

5. Kim K. D., Becker-Cohen M., Serakos M. The processing and treatment of mentally ill person in the criminal justice system, Urban institute. 2015. March. 58 p.

6. Sapers H., Zinger, l. Annual report of the Office of the Correctional Investigator 2011-2012.0ttawa, Ontario: The Correctional Investigator of Canada. Available from: http://www.oci-bec.gc.ca/cnt/rpt/annrpt/ annrpt20112012-eng.aspx. [reviewed 2020.08.28].

7. Sorenson K. Mental health and drug and alcohol addiction in the federal correctional system. Report of the Standing Committee on Public Safety and National Security. Ottawa, Ontario: Government of Canada. Available from: https://www. ourcommons.ca/Content/ Committee/403/SECU/Reports/RP4864852/securp04/securp04-e.pdf. [reviewed 2020.08.28].

8. Statistisches Bundesamt, Rechtspflege, Strafverfolgung, Fachserie 10 Reihe 3 (Statistisches Bundesamt 2013). 369.

9. Myroniuk T., Levchenko , Y. Problems Issues for Police Care for a Person who has the Signs of a Strong Mental Disorder and Creates a Real Danger of Anywhere. Scientific Herald of the National Academy of Internal Affairs. 2020;113(4):104-111. doi.org/10.33270/01191134.104. (Ua)

10. Zaviazkina N. Features of Criminal Behavior of Persons with Mental Disorders, which Were Found to Be Limited Sane. Problems of modern psychology: Collection of research papers of «Zaporizhzhia National University» and G. S. Kostiuk Institute of Psychology NAPS of Ukraine / edited by S. D. Maksymenko, N. F. Shevchenko, M. H. Tkalych. Zaporizhzhia: ZNU. 2020;49:37-59. doi.org/10.32626/2227-6246.2020-49.

11. WHO. (2019). Prevalence of mental disorders. Available from: http:// www.euro. who.int/en/health-topics/noncommunicable-diseases/ mentalhealth/data-and-resources. [reviewed 2020.08.28].

12. WHO. (2019). Fact sheet - Mental health (2019). Available from: https://www. euro.who.int/_data/assets/pdf_file/0004/404851/ MNH_FactSheet_ENG.pdf. [reviewed 2020.08.28].

13. Stuckenberg, C.-F. Comparing Legal Approaches: Mental Disorders as Grounds for Excluding Criminal Responsibility. Bergen Journal of Criminal Law \& Criminal Justice.2016;4(1):48-64. doi.org/10.15845/ bjclcj.v4i1.1026

14. Sparr. L.F. Personality Disorders and Criminal Law: An International Perspective. Journal of the American Academy of Psychiatry and the Law. 2009;37 (2):168-181.

15. Simon R.J., Ahn-Redding H. The Insanity Defense the World Over (Global Perspectives on Social Issues). Lexington Books, 2006. 245 p.

16. Loughnan A. Manifest Madness: Mental Incapacity in Criminal Law. Oxford: Oxford University Press, 2012. 266 p.

17. Rahmdel M. Mentally ills in the Iranian criminal justice. Location: Misión Jurídica: Revista de derecho y ciencias sociales. 2017;10(12):201-214.

18. International statistical classification of diseases and related health problems. - 10th revision, edition 2010. 3 v. Contents: v. 2. Instruction manual. World Health Organization 2011. 201 p. Available from: https://www.who.int/classifications/icd/ ICD10Volume2_en_2010. pdf. [reviewed 2020.08.28].
19. Teixeira E.H., Dalgalarrondo P. Crime, psychiatric diagnosis and victims' profiles: A study with the sample of a criminal-psychiatric ward in São Paulo. Jornal Brasileiro de Psiquiatria. 2006;55(3):192-194.

20. Garbayo J., Relvas Argôlo M.J. Crime e doença psiquiátrica: perfil da população de um hospital de custódia no Rio de Janeiro. Jornal Brasileiro de Psiquiatria. 2008;57(4):247-252.

21. Fazel S., Lichtenstein P., Grann M., et al. Risk of violent crime in individuals with epilepsy and traumatic brain injury: a 35-year Swedish population study. PLoS Medicine. 2011;8(12):e10011500. PMID:22215988

22. Batyrgareeva V.S. Retsydyvna zlochynnist v Ukraini: sotsialno-pravovi ta kryminolohichni problem. [Recidivism in Ukraine: socio-legal and criminological problems]. Monograph. H.: Pravo, 2009.576 p. (Ua)

23. Pondé M.P., Caron J., Mendonça M.S, Freire A.C., Moreau N. The Relationship Between Mental Disorders and Types of Crime in Inmates in a Brazilian Prison. Journal of Forensic Sciences. 2014;59(5):1307-14. doi: 10.1111/1556-4029.12462.Epub 2014 Apr 8.

24. David J. Vinkers, Edwin de Beurs, Marko Barendregt, Thomas Rinne, HansW. Hoek. The relationship between mental disorders and different types of crime. Criminal Behaviour and Mental Health. 2011;21(5):307320. doi.org/10.1002/cbm.819.

25. Männynsalo L, Putkonen H, Lindberg N, Kotilainen I. Forensic psychiatric perspective on criminality associated with intellectual disability: a nationwide register-based study. Journal of Intellectual Disability Research. 2009;53(3):279-88. doi: 10.1111/j.1365-2788.2008.01125.x. PMID: 19250388.

26. Kozerackaya, E. (2018). Criteria for limited sanity in persons who have committed criminal sexual offenses. Psychosomatic Medicine and General Practice 3, e030197.doi:10.26766/pmgp.v3i1.97

\section{ORCID and contributionship:}

Anna S. Politova: 0000-0002-7351-7110 A,B,E,F

Mykhailo O. Akimov: 0000-0001-7715-0259 D,F

Liubov M. Knyazkova: 0000-0001-6681-980X

\section{Conflict of interest:}

The Authors report no conflict of interest.

\section{CORRESPONDING AUTHOR}

\section{Anna S. Politova}

Donetsk Law Institute of Ministry of Internal Affairs of Ukraine

145, Budivelnykiv avenue, Mariupol, Ukraine

tel: +380508715865

e-mail: politova1954@gmail.com

Received: 01.09 .2020

Accepted: 30.11 .2020

A - Work concept and design, B - Data collection and analysis, C - Responsibility for statistical analysis,

D-Writing the article, $\mathbf{E}$-Critical review, $\mathbf{F}$ - Final approval of the article 